Article

\title{
Toward the Eco-Narrative: Rethinking the Role of Conflict in Storytelling
}

\author{
Corinne Donly \\ Department of English, Brooklyn College, Brooklyn, 11210 NY, USA; Corinne.donly97@brooklyn.cuny.edu \\ Academic Editor: Joela Jacobs \\ Received: 16 January 2017; Accepted: 3 April 2017; Published: 10 April 2017
}

\begin{abstract}
Offered as a response to the increasingly popular call within the eco-humanities for stories that will help humankind adapt to catastrophic planetary conditions, this article proposes "the eco-narrative" - an approach to storytelling that strives to compose with, not for, its nonhuman characters. An extension of eco-critical projects that analyze stories for their depictions of nonhumanity, the theoretical research herein brings ecological analysis of narrative to the level of structure. In particular, it problematizes the dominant plot model of conflict/climax/resolution, suggesting that stories motivated by conflict reinforce dualistic and anthropocentric habits for approaching the animal other. Evaluating two narratives concerning the human practice of killing animals-the Pew Commission's report on Industrial Farm Animal Production and Annette Watson and Orville H. Huntington's "They're here-I can feel them" - the article observes how the former's efforts at animal rights advocacy are undermined by its very storytelling framework. Celebrating the latter story's more playful approach to narrative instead, the article ultimately suggests that a theory of "infinite play," as developed by James P. Carse, can be used to re-envision the dominant plot model. A template for cooperation in the absence of known outcome, infinite play thus becomes the basis for the eco-narrative-a storytelling framework flexible enough to cocreate with nonhumanity, even during an environmental moment characterized by crisis.
\end{abstract}

Keywords: eco-humanities; eco-criticism; eco-philosophy; Industrial Farm Animal Production; narrative; plot; conflict; environmental crisis; catastrophe; play theory

\section{Introduction}

Scholarly appeals to the "universal" of storytelling easily split in two directions. Some focus on story as it arises developmentally across the human species (Boyd 2009; Paley 2004). These scholars have tended to emphasize the narrative quality of children's fantasy play, highlighting the importance of story to the cultivation of social connectivity and to early experiences of agency (Paley 2004). Story, it has been argued, provides children with the capacity to exert influence upon their worlds and to feel themselves participating in the determination of outcomes. Within this developmental framework, some have also attempted the grander project of tracing the biocultural and evolutionary origins of story. Brian Boyd, in particular, has suggested that the survival of the human species has depended upon strong group cohesion, and as such, stories have served the evolutionary function of teaching groups the norms that will ensure cooperation (Paley 2004). Importantly, Boyd attempts to locate what is evolutionarily efficacious about storytelling within any species, and thus, his search for the biocultural basis of narrative reaches well beyond the realm of the human. For Boyd, as for developmental psychologists, the human drive to tell stories emerges out of an impulse common to almost all animals-that of play. Indeed, in animals and children alike, it is open-ended play that encourages the low-stakes practicing of skills that may later prove essential to survival.

Other scholars have attempted to make a structural argument about the way in which stories are told, suggesting that all stories contain the same essential ingredients and can be 
codified into a basic, recurrent model. Emerging in the late 1960's out of structuralist theory, and premised as the "characterisation of the model underlying people's intuitive knowledge about stories" (Herman 2005b, p. 572), the field of narratology has itself been accused of a universalistic failure to consider "history and context" (Warhol 2012, p. 9). As the field has expanded, however, avenues of narratological investigation have moved evermore toward the inclusion of "contextualist narratologies" (James 2015, p. 14). Accordingly, underneath the larger umbrella of narratology can now be found sub-fields like feminist/queer narrative theory-dedicated to understanding texts via "the material circumstances of the history that produces and receives them" (Warhol 2012, p. 9)—and unnatural/antimimetic narratology, which situates its analysis on texts that "challenge rather than conform to" the conventions of realist narrative (Richardson 2012, p. 22). As with other movements into the postmodern, these expanded conceptions of narratology are largely focused on texts hitherto ignored by more traditional narrative theory. Yet, even as academic inquiries into narrative structure have enacted a shift away from essentialism, more popular explanations of narrative remain, on the whole, dedicated to the project of presenting a single, easily replicable account of how story happens.

In The Storytelling Animal, for instance, Jonathan Gottschall contends that stories display a "universal grammar." As he explains, "Almost all story makers work within the tight confines of problem structure...writing stories around a pattern of complication, crisis, and resolution" (Gottschall 2012, p. 54). In formulating this pattern, Gottschall cites other analysts of narrative-namely Janet Burroway and Charles Baxter-who have positioned "conflict" as the foundational element of fiction (Gottschall 2012, p. 52). Indeed, these thinkers follow in a long tradition of writers who, in various (and admittedly less scholarly) handbooks on the craft of fiction, attempt to reduce the act of storytelling into a repeatable formula. Although there are slight variations in how this formula gets described, the basic pattern recalls the "plot-stages" identified in 1959 by Cleanth Brooks and Robert Penn Warren: "exposition, complication, climax, and denouement" (Herman 2005a, p. 83), and the general consensus, even today, is that "without conflict, plot hardly exists" (Harmon and Holman 2003, p. 387). A successful story therefore tracks a protagonist as he moves through an experience of conflict, and regardless of what the conflict entails, it must escalate until it reaches a moment of climax-"the point where something has to give-and does" (Kress 1993, p. 71). As these models would have it, "resolution" is only available on the other side of a crisis (Dibell 1988, p. 126).

In arguing for this "universal grammar," Gottschall is not merely making a case about what exists today as a practiced storytelling habit; he is suggesting that this storytelling structure can be detected "No matter how far we travel back into literary history, and no matter how deep we plunge into the jungles and badlands of world folklore" (Gottschall 2012, p. 55). In Gottschall's estimation, as long as humankind persists, so too will this narrative pattern (Gottschall 2012, p. 186). Especially when set against traditions of the literary avant-garde, any appeal to a storytelling model that is "universal" in both its geospatial and temporal dimensions seems overly simplistic at best. Nevertheless, Gottschall and his fellow fictionists are correct in highlighting, if nothing else, the prevalence of a storytelling method that has not heretofore undergone much scrutiny. While I concede, therefore, that this has become a popular-and potentially reified—formula for constructing stories, I prefer to resist Gottschall's appeals to the "universal." Instead, I conceive of this formula as the "dominant Western plot model," and I suggest, further, that the status of "dominant" need not excuse the model from critique. If anything, it signals a pressing need to investigate the model further-following in the footsteps of feminist narrative theorists and unearthing the links between popular narrative structure and other forms of domination.

It is also worth briefly observing that, despite the fact that these two accounts of storytelling "universals" are categorically distinct-that is, that one account pursues the evolutionary origins of story, while the other examines storytelling practices on a structural level—they need not be at odds with one another. Indeed, one would suspect that if a storytelling model were truly "universal" across the human species, a biocultural explanation would easily extend beyond the origins of story and into the format that stories have tended to assume. The above two accounts seem irreconcilably opposed, 
however, with regard to the role of conflict vis-à-vis storytelling. Whereas adherents to the dominant Western plot model contend that story cannot exist in the absence of conflict, Boyd repeatedly stresses that storytelling has evolved for the purpose of teaching cooperation (Boyd 2009). He even suggests that, although people are often hesitant to apply evolutionary frameworks to human behavior precisely because they imagine evolution to be driven by conflict_-"stressing selfishness and competition at the expense of altruism and cooperation" - "sociobiology's central preoccupation has been cooperation" (Boyd 2009, p. 26). In Boyd's terms, then, evolution has been more significantly facilitated by mutualism than by competition, and story is, in fact, a human evolutionary development to promote the former. Equally significant, Boyd also emphasizes the importance of narrative novelty to human learning. Because humans cease to respond to patterns that become predictable, there is considerable pressure on all art-including the art of storytelling_to "violate our categoric expectations" (Boyd 2009, p. 115). This would seem to suggest that a storytelling model that has become formulaic cannot fully engage its audiences or, at the least, no longer functions as a mechanism for the cognitive evolution of the human species. To the extent that the dominant plot model has become pervasive, then, it has simultaneously sacrificed its ability to stimulate learning. Thus, even on a biocultural level, it is a formula that deserves to be rethought.

What is more, considering the increasing prevalence of philosophical and ecological arguments that identify the present moment as exceptionally catastrophic and, concurrently, call for new ways of being human, any appeals to an inviolable formula need face heightened scrutiny. At this point, talk of crisis-emerging from discourses as diverse as those of global warming, species extinction, economic inequity, etc.- - has infiltrated even the most mainstream of channels, and it is no longer uncommon to hear casual end-of-world forecasting. In fact, the apocalyptic narrative has become so popular-both in fictional media and in scientific discussions—that some, like eco-humanities scholar Frederick Buell, have suggested that crisis can no longer be considered a singular, temporal event; rather, it must be seen as a condition that humankind dwells within (Buell 2003). Similarly, as of 2012, a group of environmentalists and economists have coined the term "catastrophism" (Lilley et al. 2012). In the broadest sense, they use "catastrophism" to refer to a generalized belief that "society is headed for collapse, whether economic, ecological, social, or spiritual" (Lilley 2012, p. 1). In a more particular sense, however, they consider "catastrophism" a phenomenon whereby people celebrate catastrophe as a shortcut out of increasingly unlivable planetary conditions. As activist Sasha Lilley explains, "Catastrophists tend to believe that an ever-intensified rhetoric of disasters will awaken the masses from their long slumber" (Lilley 2012, p. 1). According to Lilley, despite its prevalence, the catastrophist mindset makes two crucial errors: In the first place, it presumes that fear is a motivating force, and second, it focuses on highly dramatic, future disasters, thereby rendering less significant the day-to-day ways that Earth is already suffering the impacts of environmental degradation.

As both Buell and Lilley indicate, then, a widespread disconnect exists between the popular catastrophist expectation that crises will force some sort of salvific or reformatory action and the reality that humankind, by all accounts, is already living within crisis conditions. Here it is worth remembering, however, that one of humanity's foremost relationships to crisis is a narrative one. As the dominant plot model would have it, crisis is the necessary fulcrum of change; a narrative conflict cannot find its resolution until it has reached its "make-or-break" climax (Dibell 1988). As such, if part of the current ecological project is to reposition humanity with regard to environmental crises, then this must occur not only within the realm of environmentalism but also within that of popular storytelling. Indeed, if Boyd's evolutionary argument is to be believed, stories play an important role in the development of the human species (Boyd 2009), and the way in which we humans tell our stories can directly impact our ability to adapt to shifting environmental conditions. Therefore, the question must become: What changes to the dominant plot model are demanded by the present-day reality of environmental crisis?

Here, it is appropriate to introduce some of the thinkers who, from more philosophical corners of the eco-humanities, have addressed the pervasiveness of crisis as necessitating a shift in how humans 
approach both art-making and their nonhuman compatriots. At the forefront of such thinking is Timothy Morton, who has recently philosophized on "hyperobjects" - a term Morton uses to describe those phenomena that, although real, are too vast and too nonlocal to be fully perceptible to human beings (Morton 2013). As Morton explains them, exemplar hyperobjects like global warming and nuclear waste-entities with which humans have a reciprocal relationship, both acting upon and being acted upon by—challenge any human attempt to narrate from "above." Precisely because hyperobjects are real, but are simultaneously of magnitudes not entirely visible or even comprehensible to the humans who have created them, they render laughable all hope of a "metalanguage that could account for things while remaining uncontaminated by them" (Morton 2013, p. 2). Of course, one hears here the echoes of feminist discourses like that of Donna Haraway, who long ago argued against "the god-trick" and instead advocated the "situatedness" of all perspective (Haraway 1999). Yet, in either case, the implications for narrative are the same. If one is to properly account for the present environmental reality-which is, of course, the reality of the hyperobject-then one must resist the narrative impulse to possess a story in its entirety. That is, in attempting to tell any story about a nonhuman other, one must dispense of the contrivance of the omniscient narrator, who professes both to be unimpacted by the story he is telling and to know the ending of the story before it has even begun.

Particularly relevant to "catastrophism," Morton also contends that hyperobjects have already brought about the "end of the world" (Morton 2013). Morton nods to the environmentalist tendency toward apocalyptic talk, arguing that it has been ineffective for precisely the reason that "to all intents and purposes, the being that we are supposed to feel anxiety about and care for is gone" (Morton 2013, p. 6). As Morton reasons, "climate" existed heretofore as the background to human activity, yet in the era of climate change, it has become the focal point of human discourse. Now brought into the foreground, "climate" can no longer be said to constitute a "world" for humans. Rather, it must be addressed relationally, as an object in its own right. Indeed, if genuine ecological progress is to be made, the concept of "world" needs to be discarded altogether:

Three cheers for the so-called end of the world, then, since this moment is the beginning of history, the end of the human dream that reality is significant for them alone. We now have the prospect of forging new alliances between humans and non-humans alike, now that we have stepped out of the cocoon of world (Morton 2013, p. 108).

For Morton, the crucial advantage to embracing "the end of the world" is that it forces a reorientation of the human toward the nonhuman other. In the absence of an all-enveloping environment, no one species or object can be said to occupy the privileged position of "protagonist," and all that remain instead are relationships. Morton views this relational reorientation as an "upgrade" in human ontology and, significantly, calls upon "philosophers and other humanities scholars" to help facilitate such an "upgrading" in their fellow human beings (Morton 2013, p. 101). Accordingly, he advocates an "object-oriented art," arguing that the proper artistic response to the era of the hyperobject is an art that conceives of itself as a collaboration between humanity and nonhumanity. This does not mean that humans are in charge of creating work about nonhumanity-as if above their nonhuman compatriots-instead, it means that humans create with nonhumanity. Morton wants an art that prizes "coexist[ence] without an agenda" (Morton 2013, p. 189).

Occupying a similar position, philosopher Isabelle Stengers contends that it already "goes without saying" that, due to climate change, the Earth may become uninhabitable for the human species (Stengers 2015, p. 7). Like Morton, she highlights the strangeness of this environmental moment, wherein we humans now regularly hypothesize about a future beyond our own demise. Categorizing these times as "catastrophic," Stengers's stated project is to prevent humanity from defaulting into "barbarism." Toward this end, she makes an appeal to new narrative strategies. Not only does she speak of the importance of "paying attention" to narratives other than the dominant ones (Stengers 2015, p. 77), she also voices a distrust in the habit of confronting others-even those economic actors who are driving the destruction of the planet-in terms that are "intelligible only on the basis of conflict" (Stengers 2015, p. 35). For Stengers, preparedness for the future depends on 
moving past conflictual narratives; it means "learning to compose" in a way that "couple[s] together multiple, divergent struggles" (Stengers 2015, p. 50).

In more popular publishing circles, humanities scholar Roy Scranton has also argued that the only way the human species can ensure its own survival is by accepting that this civilization, in its current carbon-driven incarnation, is "already dead" (Scranton 2015, p. 23). For Scranton, releasing those habits of capitalism that are presently driving humanity toward its own demise will be the best way to ensure that we humans can "adapt" to our imminent catastrophic future. Like Stengers and Morton, Scranton sees human adaptability as dependent upon philosophic interventions that can supply humans with "new myths and new stories" (Scranton 2015, p. 19). Indeed, it is a new type of humanity that Scranton desires, and he calls upon storytelling to lead the way toward it.

All three of these thinkers suggest that, in the face of doom, humans must learn to inhabit their humanness in new and more selfless ways. Most significantly, however, all link this "upgraded" humanness to the cultivation of new narratives or new narrative habits. Agreeing that humanity—particularly Western capitalistic humanity—has become habituated to behaviors that are disproportionately self-interested and unnecessarily conflictual, I echo the sentiment that humans need new stories. I also suggest, however, that we need new templates for constructing our stories. As indicated above, the dominant narrative model holds that story cannot exist in the absence of conflict, yet this perspective seems exceptionally ill-suited to contend with environmental crises-existing and forthcoming - that call for human adaptability. Indeed, considering that evolution occurs in response to shifting environments and that it often depends more on cooperation than on competition (Boyd 2009), it seems prudent to embrace Morton's advice and learn to create with, rather than against, our environments and our nonhuman compatriots (Morton 2013). This means seeking out those stories that promote a cross-species mutualism, even on the structural level-that is, no longer identifying a story as successful merely because it accompanies a single (human) protagonist as he engages in a conflict.

What is more, if the ongoing crises heralded by climate change and species extinction are to be taken seriously, then the narrative role of crisis must also be reconsidered. Storytelling's reliance upon a crisis that is "bad enough" to force conclusion must be seen as incommensurate with the reality that environmental crises are not instantaneous, life-altering events; rather, they have become the protracted and overlapping landscapes with which humanity presently dwells (Buell 2003). Indeed, if the world has already ended, then no crisis-not even those belonging to the increasingly popular apocalyptic genre-can be said to bring about an ending to the human/Earth story. Resisting the impulse toward "metalanguage" (Morton 2013), then, we humans must learn to tell our stories from inside of them. Facing tremendous uncertainty-in the absence of the "world" we've long taken for granted-we would do well to rethink the habit of armoring ourselves for narrative battle and, instead, redirect our stories and our energies toward that which has consistently aided our adaptation: constructive relationships.

Conceived as a response to the popular call for both new narratives and new philosophical orientations toward nonhumanity, then, this article thinks toward more relational and ecosystemic ways of constructing stories. As far as lineage is concerned, it can be linked, most immediately, to Erin James's "econarratology" - an analytical approach to story that unites the interests of both ecology and narratology, "studying the relationship between literature and the physical environment, but do[ing] so with sensitivity to the literary structures and devices that we use to communicate" (James 2015, p. 23). According to James, "econarratology" is a necessary extension of eco-criticism, which has tended to focus too heavily on content, thereby excluding from its analyses the formal dimensions through which stories communicate about their environments (James 2015, p. 4). Directing her own econarratological analyses at postcolonial texts, James suggests that the structure a text enacts is often already a site of resistance. Thus, by developing a narrative theory capable of reading and responding to literary structures that have emerged in direct reaction to Western hegemonies, eco-criticism 
can simultaneously encourage new, more equitable models for how humans might relate to their environments (both on and off of the page).

I heartily endorse James's belief that narrative structures are often already modes of resistance. I am also deeply interested in the reciprocal relationship between texts and their environments-in how storytelling forms not only emerge from environments but also have the power to "reshape individual and collective environmental imaginations" (James 2015, p. 39). Insofar, however, as my interest ultimately lies more with the "reshaping" effort-that is, with the telling of stories rather than with their interpretations-my own project is perhaps better named as an ecompositional one. Like eco-criticism, ecocomposition is premised upon the belief that environments both impact and are impacted by discourse (Dobrin and Weisser 2002, p. 9), and indeed, ecocomposition theorists suggest that the environmental crisis places a heightened demand on humans to understand how their language systems participate in practices of domination (Dobrin and Weisser 2002, p. 20). Ecocomposition distinguishes itself from eco-criticism, however, in that "Ecocriticism is a literary criticism that looks toward textual interpretation," whereas "ecocomposition works from the same place, but is concerned with textual production" (Dobrin and Weisser 2002, p. 24). Yet even while this is the case, ecocompositionists also acknowledge that it is "nearly impossible" to make a clean separation between interpretation and production, for "studying textual representations of nature is critical to the understanding of how textual production occurs" (Dobrin and Weisser 2002, p. 41). Similarly, even though my goal in this article is to reposition the storyteller with regard to the story-considering how any person crafting a narrative can effectively resist the structuring temptations of the dominant plot model-I arrive at such considerations only after performing econnarratological analyses of nonfiction texts. Throughout these analyses, my guiding interest concerns how narrative structure has been conceived and reproduced within Western storytelling practices at large. In other words, I care most about the effect that a continually reinscribed narrative pattern of conflict/climax/resolution has had on people's everyday efforts to make sense of their environments.

Indeed, at the heart of this project is a belief articulated by Peter Brooks, scholar of comparative literature, who has suggested that there is "a correspondence between literary and psychic dynamics, since to an important degree we define and construct our sense of self through our fictions" (Brooks 1984, p. 36). As Brooks makes clear, our stories and our perceptions comprise a feedback loop; the way we experience story necessarily becomes the template by which we understand our own existence.

This perspective, it is worth observing, is concordant with cognitive narratologists' concept of the "storyworld" - a concept that is itself foundational to James's econarratology (James 2015). As James explains the term, a storyworld refers to "the world-creating power of narratives that catalyzes an imaginative relocation of readers to a new, often unfamiliar world and experience" (James 2015, p. 11). Storyworlds are of particular interest to James, then, because they are environmental in nature; they not only ask readers to inhabit the storyworld of a text, but they necessarily serve as a point of comparison between the textual world and the everyday one that the reader inhabits. Within the difference between these two worlds emerges the narrative's power to reshape readers' thinking. As David Herman observes, "narrative affords methods—indeed, serves as a primary resource-for world-modeling and world-creation" (Herman 2012, p. 15). There is an explicit link, then, between how stories communicate their environments to their readers and how readers learn to communicate their environments to themselves. Narrative practices are educational.

It is in this spirit that I here propose "the eco-narrative"-a more ecologically responsible framework through which storytellers can enter into their storytelling practices. My foremost purpose in suggesting the eco-narrative is to provide storytellers with an alternative to the dominant plot model - that is, a way of enacting formal narrative choices that will constitute a resistance, in and of themselves, to storyworlds premised upon conflict. It is my contention that, whether or not we tell stories explicitly about our Earthly environments, we can consider it a significant environmental intervention to rethink how we are telling any story. Just by resisting the initial premise that a story 
must always emerge from a conflict, we can simultaneously teach new, mutualistic models for approaching nonhumanity.

In invoking the eco-narrative, I am aware that the term has already been employed to name a category of narrative associated with "environmental storytelling" (Heise 2005). Indeed, within her entry on "eco-narratives" in the Routledge Encyclopedia of Narrative Theory, Ursula K. Heise identifies the wide number of ways that stories about environments have already manifested. She includes in her entry, for instance, genres commonly associated with environmental narrative (e.g., "nature writing"), as well as those narrative "experiments" (e.g., the use of an animal narrator) meant to "relativiz[e] modern, human-centered viewpoints" (Heise 2005, p. 130). In attaching the term "eco-narrative" to my own project, I certainly do not mean to represent all of these manifestations. More accurately, I am proposing a specific, formal avenue through which stories can earn their entry into the broader category that Heise has outlined. Above all, I intend my use of the term "eco-narrative" to signal a kinship with James's econarratological efforts, which share my interest in the communicative properties of a story's structure. That said, I am invested in the experimental narrative strategies through which Heise recognizes some eco-narratives, and I take inspiration (in particular) from work that has explored animal narrators and their particular capacities to "destabilize anthropocentric ideologies" (Bernaerts et al. 2014, p. 74). What is more, my own endeavor is explicitly motivated by the storytelling "challenge" with which Heise ends her entry-that of "developing modes of narration that convey a sense of ecosystems not only in their local and regional manifestations, but also in their global reach" (Heise 2005, p. 130). The eco-narrative I advocate here is precisely an attempt to "convey a sense of ecosystem" via narration.

In its broadest incarnation, this eco-narrative project would outline all of the (potentially infinite) avenues though which a storyteller might use form to convey ecosystem. To reiterate, however: My specific purpose within this article is to rethink the function of "conflict" as it has been presented within the dominant plot model. Because I share Morton's belief that the art most likely to guide humanity through and beyond "the end of the world" is one that prizes relationships-attempting to compose with, not for, the nonhuman other (Morton 2013) -I focus herein only on stories that concern nonhumanity. In particular, I consider examples of how animals appear within human narratives. Even though Morton's object-oriented art sees an elephant and a plastic bag as equally viable compositional partners, I prefer to limit myself to addressing the nonhuman animal, not only because the leap to another sentient being may be easier for the anthropocentrically entrenched, but also because animals figure prominently in the tales told by young children when they are first learning to construct their worlds through story. As such, even though this article responds to narrative in its widest manifestations-from children's fantasy stories to the more disguised narratives of science-it seeks to exert influence on only the smallest and most private of levels: the way in which we humans position ourselves with regard to the stories we tell.

To this end, the article invokes three shifts. The first aims to expose the structural limitations of the dominant plot model, particularly when it is applied to nonfiction accounts of the animal other. In this section, I analyze the Pew Commission's 2008 report on Industrial Farm Animal Production (Carlin et al. 2008), pointing to evidence of how a conflictual and anthropocentric framework imposes itself, even within the realm of scientific reportage. Against the dominant narrative reinforced by the Pew report, then, the second shift proposes new directives by which the storyteller can craft narratives that are less driven by conflict. Returning to that which evolutionary theorists and developmental psychologists have commonly identified as the basis for story, I root these directives in play theory - that is, I identify those values of play that might easily transpose themselves into storytelling practices. In this way, play becomes the guiding principle of the eco-narrative that I propose within the third and final shift. Here, I not only discuss the precepts of the eco-narrative in theoretical terms, I also analyze an example of an eco-narrative in practice. Using Annette Watson and Orville H. Huntington's "They're here-I can feel them: the epistemic spaces of Indigenous and Western Knowledges" as a model text (Huntington and Watson 2008), I explore a narrative that more 
successfully includes the animal other-exhibiting values of play both within its narrative practices and within its depiction of human/animal interactions.

\section{The Animal as Antagonist: Conflictual Storytelling in Practice}

In 2006, the Pew Commission on Industrial Farm Animal Production-consisting of fifteen experts in diverse fields connected with the U.S. agricultural industry-convened to investigate the practice of Industrial Farm Animal Production (IFAP) and its implications for human and animal welfare (Carlin et al. 2008). Two years later, the Commission published its findings in a report, Putting Meat on the Table: Industrial Farm Animal Production in America. The report is ultimately critical of IFAP, noting that it "presents an unacceptable level of risk to public health and damage to the environment, as well as unnecessary harm to the animals we raise for food" (Carlin et al. 2008, p. 8), and it concludes by proposing recommendations to enhance IFAP's sustainability. Importantly, these recommendations are not only aimed at improving the health of the humans who regularly consume animal protein, but they also suggest some ethical standards whereby animals raised for consumption can enjoy more humane living conditions. However, even in their attempts to critique Concentrated Animal Feeding Operations (CAFOs) - and to act justly on behalf of the pigs, cows, and chickens who inhabit them-the authors of the Pew Report enlist (either intentionally or unintentionally) the conflictual patterning of the dominant plot model. In the preface to the report, the Executive Director of the Commission, Robert P. Martin, even states, "The story that follows is the Commission's overview" (Carlin et al. 2008, p. 9). Referring to the report itself as a "story," he alludes to its narrative underpinnings, perhaps suggesting that the report represents the Commission's attempt to "emplot" various pieces of data into a recognizable narrative format (White 2002). Moreover, although Martin does not specify how that data has been arranged - that is, what kind of tale is being told—it is clear, even from the title, that it will necessarily be a story about animals, as told by humans.

The most revealing aspect of the Pew Report's "story" is, in fact, the history it gives for IFAP. As told by the report, the origins of the CAFO belong to the timely confluence of the Green Revolution with the development of the mechanized slaughterhouse in the United States. Emerging out of a post-World War II period of affluence, the Green Revolution was a "worldwide transformation of agriculture that led to significant increases in agricultural production from 1940 through the 1960s" (Carlin et al. 2008, p. 3). This "revolution" brought the first uses of pesticides, chemical fertilizers, and genetic selection within agriculture, and it was evaluated as successful insofar as it resulted in crop yields that met and "even outpac[ed] the demands of the rapidly growing world population" (Carlin et al. 2008, p. 3). Such agricultural productivity made corn and grains abundant enough to become staples in the diets of both humans and animals, and it therefore became profitable to use surpluses toward large-scale animal agriculture. In the report's own language:

...the ready availability of inexpensive grain and the rapid growth of an efficient transportation system made the United States the birthplace for intensive animal agriculture. Paralleling the crop yield increases of the Green Revolution, new technologies in farm animal management emerged that made it feasible to raise livestock in higher concentrations than were possible before. As with corn and cereal grains, modern industrial food animal production systems resulted in significant gains in production efficiency (Carlin et al. 2008, p. 5).

As is evident above, from the very outset, the history of IFAP is one explained in terms of "efficiency." The report cites increased production capabilities as important to providing food for a growing human population, and indeed, the benefits of "efficiency" continue to be celebrated, even as the report moves into the present-day. For example, the report notes that the "widespread adoption of IFAP facilities [has] led to widely affordable meat, poultry, dairy, and eggs" (Carlin et al. 2008, p. 7). This has had the effect that "animal-derived food products are now inexpensive relative to disposable 
income" (Carlin et al. 2008, p. 7). The report even adds that, at present, U.S. citizens consume more animal products per person than the citizens of any other country (Carlin et al. 2008, p. 7).

Summarizing the total trajectory of animal agriculture-from early animal husbandry to the present-day practices of IFAP-the report eventually explains:

Industrial farm animal production (IFAP) stands in stark contrast to previous animal farming methods because of its emphasis on production efficiency and cost minimization. For most of the past 10,000 years, agricultural practice and animal husbandry were more or less sustainable, as measured by the balance between agricultural inputs and outputs and ecosystem health, given the human population and rate of consumption. IFAP systems, on the other hand, have shifted to a focus on growing animals as units of protein production (Carlin et al. 2008, p. 23).

Importantly, the report goes on to suggest that this shift of focus-from "balance[d] agricultural inputs and outputs" to "animals as units of protein production"—is precisely what has driven IFAP to unsustainability. As CAFOs have turned their attention toward increased production-that is, toward raising more and more animals in less time and less space - they have had to resort to practices like feeding antibiotics to animals and disposing of animal waste in amounts exceeding what the land is able to absorb. These practices, as the report notes, are unquestionably detrimental to the environment and to the health of both humans and animals, alike.

To be sure, then, the Commission sees IFAP as presenting a grave problem, yet by the time it arrives at its critique, the narrative damage has already been done. Because the history of IFAP has been presented as one of efficiency, its trajectory toward these unsustainable and unhealthful practices emerges as inevitable. Repeatedly emphasizing the benefits of cheap meat-that is, stressing the economic advantages for the U.S. consumer (while remaining silent about the fiscal incentives of the producers) - the report positions even the most distasteful of IFAP practices as the consequence of efficiency measures. As such, the practices can be conceived of in relatively innocent terms-as necessary to continuing to supply affordable animal products to a population that also continues to grow. In this way, the report thinks from an overtly human position, evaluating IFAP with regard to how it either benefits or harms U.S. consumers.

Considering that the report has an entire section dedicated to "Animal Welfare"-wherein it endorses the "five freedoms" adopted by the Farm Animal Welfare Council (Carlin et al. 2008, p. 35) - the authors of the Pew Report would probably contend that they have done a more than adequate job of representing animals. While their stated consideration of animal welfare is important, however, it is simultaneously undermined by the narrative practices of the report. Precisely because the efficiency narrative has situated the economic advantages to human consumers at the direct expense of animals' ethical living conditions, the history of IFAP is a story with only two main characters: the humans who rely on affordable animal protein and the animals who become that protein. Even the companies that have "vertically integrated" toward increased efficiency—arguably, the main actors in the real-world events of the story-are allowed to assume a certain narrative anonymity. As the report would have it, these companies did not create and implement practices founded on questionable ethics; rather "new technologies ... emerged" that made meat affordable for consumers. In this way, the report places the focus of the history not on corporations that deserve scrutiny, nor on animals who deserve advocacy, but on humans who had (and continue to have) a basic need for affordable meat. The report asks, in other words, that readers empathize with U.S. consumers, placing their goals above all others'.

Toward this end, Boyd observes that narrative has been evolutionarily useful in cultivating empathy, precisely because it has taught listeners to "recognize others' goals and desires" (Boyd 2009, p. 138). Complicating this perspective, Suzanne Keen, in her book Empathy and the Novel, casts doubt upon the assumption that stories always generate empathy, suggesting that even when they do, there is no guarantee that such empathy will translate into "altruistic" behavior (Keen 2007). Keen also suggests, however, that the ability of story to engender empathy may not always be a virtue, as empathy can be 
felt toward undeserving parties. By asking readers to view the development of IFAP through the lens of the consumer-identifying with what might rightly be described as a false (privileged, Western) "need" to eat high quantities of meat-the Pew report attempts to offer the U.S. consumer the empathic privileges of a protagonist. Observing Keen's warning, however, readers of the Pew Report should be suspicious of whether or not their empathy is being justly directed.

Of course, as U.S. consumers step into their role of the protagonist in the Pew report, the animal inhabitants of the CAFO necessarily become the antagonist. This does not happen, however, through an explicit denouncement of the animals—-for whom the report finally hopes to advocate-but through far subtler literary practices. Because the history has been presented in a predictably narrative way - with the wellbeing of farm animals placed directly at odds with the needs of a growing human population - a conflict is established at the very origin of IFAP's history. It cannot be seen as harmless that the report celebrates the advantages of consumer access to "widely affordable meat," as even this celebration pushes the humans and animals into prefigured, oppositional roles of protagonist-consumer and antagonist-consumed. What is more, because of the inverse nature of the conflict-with increased efficiency directly resulting in a decreased quality of animal life-it is a conflict positioned, like all conflicts within the dominant plot model, to escalate until it constitutes a crisis. The very fact that the Pew report finally labels contemporary IFAP practices as unsustainable, then, should come as no surprise; its history was written to build to this point. The ultimate danger, however, is that because the history pits human welfare against animal welfare-and because it encourages identification with a human protagonist - the story cannot ever escape its anthropocentric bias. Despite its best intentions, it will always be an account that views animals through a human lens-pitying them, perhaps, but nevertheless denying them of any narrative autonomy.

With this in mind, it is useful to introduce eco-feminist Val Plumwood's understanding of dualism, which she describes as "the construction of a devalued and sharply demarcated sphere of otherness" (Plumwood 1993, p. 41). Differentiating dualisms from distinctions or dichotomies, Plumwood points to the reliance of dualism on hierarchical systemizations, whereby dominant perspectives naturalize the radical exclusion of any others (Plumwood 1993, p. 47). The field of ecocomposition, it is worth noting, has explicitly built off of Plumwood's work, addressing the "discursive maneuvers that create dualistic splits" (Dobrin and Weisser 2002, p. 10). As the ecocompositionists make clear, "demarcated sphere[s] of otherness" are frequently inscribed and reproduced via rhetorical practices. In its explicit prioritization of human interests over animal interests, then, the history of IFAP would seem a textbook example of a discursive dualism at work. Within this history, animals are not considered as sentient beings capable of agency; rather, they are viewed only in terms of what they can provide for their human counterparts. Plumwood labels this tendency of the dominant to regard the other in terms of its usefulness as "instrumentalism." She explains, "The dualising master self does not empathically recognise others as moral kin, and does not recognise them as a centre of desires or needs on their account" (Plumwood 1993, p. 53). Within the story of IFAP, animals are not the main characters-and, indeed, never can be-precisely because they are not granted any storytelling agency.

Incidentally, this emphasis on the dominant failure to regard the other as "moral kin" recalls an argument by utilitarian scholar Gaverick Matheny, who suggests that any truly ethical perspective must give equal weight to the interests of everyone involved in a story, including (in this case) industrial farm animals (Matheny 2006, p. 13). According to Plumwood, however, instrumentalism reflects an inability of the dominant to even conceive of the other as having separate interests (Plumwood 1993). Instead, the other is a tool by which the dominant realizes personal desires. In this sense, IFAP, as a practice, is not susceptible to the utilitarian arguments popular with animal rights' advocates, precisely because it does not conceptualize of animals as anything other than objects for human use. For this reason, the attempt of the Pew report to inject an ethical standard into IFAP by way of the "five freedoms" is incommensurate with the dualising narrative practices whereby the report has already constructed animals as instruments of humanity. 
Evidence of this failure to view animals as "centres of desire" is perhaps most apparent in the Pew report's treatment of farm animals as symbols. Defined in literary usage as "a specially evocative kind of image; that is, a word or phrase referring to a concrete object, scene, or action which also has some further significance associated with it" (Baldick 2004, pp. 251-52), the symbol is the literary counterpart to the "object." To make something symbolic is to involve it in a narrative apart from its own-to suggest that its relevance is contextual to its interpreter. In his Theory of Religion, Georges Bataille writes, "to kill the animal and alter it as one pleases is not merely to change that which doubtless was not a thing from the start; it is to define the animal as a thing beforehand" (Bataille 2011, p. 168). Indeed, as noted above, IFAP seems reliant on a conception of the animal as a thing (specifically a tool) for human use. As an extension of Bataille's idea, however, narrative theorists have also observed that "a lot of non-human narratives point to the fact that people may conceive the other (person, animal) as an object in order to cope with reality" (Bernaerts et al. 2014, p. 70). Taken from this perspective, the narrative thing-making of animals, within any story, might reflect a psychological tactic whereby meat-eaters distance themselves from the "reality" of their actions. The Pew report seemingly capitalizes off of this psychological distancing, asking its audience to regard animals not as living and breathing creatures, but as the means by which man is able to provide for himself-that is, as food.

More to the point: The way that the CAFO turns the animal into a symbol is, of course, a rhetorical practice; it happens by way of language. In the above excerpts, the Pew report notably refers to animals as "units of protein," and indeed, the entire practice, insofar as it is labeled "Industrial Farm Animal Production," erroneously suggests that humans are responsible for the manufacture of animal life. This deliberate renaming not only encourages a denial of animal sentience but also positively revalues the killing of an animal as a creative act that generates "product." Insofar as it "define(s) the animal as a thing" - as a "unit" - before that animal even exists, IFAP does not entertain the possibility of the animals it exploits ever existing independently of one another or in non-symbolic incarnation. CAFO animals never cease to be viewed as the profit-generating objects that they will finally become.

All of this results in a story wherein the antagonists-that is, the animals whose welfare, were it to be improved, would necessarily be at the expense of human consumers-are robbed of their literal as well as their narrative agency; they are not treated as living beings, and as such, they do not merit the reader's identification. Converted into economic terminology from the outset, the animals lose even their status as animals. It is significant, therefore, that the Pew report is explicit in its goals of granting CAFO animals those "freedoms" that will ensure their welfare, for such goals are contradicted by the very rhetorical practices that the report enacts. By invoking the precepts of the dominant plot model-appealing to a history that is defined by an exclusively human struggle for sufficient and affordable food-the report asks readers to see their needs as being in conflict with those of the animals they eat. Further, by portraying the human protagonist against a backdrop of scarcity - that is, an environment that cannot meet the demands of a growing population without the interventions of IFAP - the report reinforces an idea that is often relied upon, according to Stengers, by those who wish to maintain control of a narrative: The idea that the status quo, unsavory as it may be, cannot risk intervention (Stengers 2015, p. 77). In this way, the dominant plot model reveals itself as an effective tool for an already dominant narrator-that is, for a narrator who has an interest in conditions remaining as they are. For the storyteller who seeks to use story as a tool for change, however, there are other narrative frameworks to be discovered.

Before moving into an exploration of such frameworks, however, I'd like to pause and briefly note: In offering the above critique, my goal is not to indict the Pew Commission as intentionally protecting an unacceptable status quo. On the contrary, the Pew report has done important work in exposing the harmful practices of IFAP. My critique is meant to suggest, however, that the narrative strategies invoked by the Pew report directly contradict its efforts at reform. The report therefore invites the question: What sort of narrative interventions would successfully reroute the history of IFAP away from its sole identification with human actors and toward a more equitable accounting for the animal 
other? Or more broadly speaking: How can authors who seek the fair treatment of animals enact this treatment, even within the stories they tell?

\section{Rethinking Narrative by Returning to Play}

In seeking new ways to approach storytelling, it is worthwhile to look toward that which precedes the development of story in humans: play. Not only has Boyd identified "cognitive play with pattern" as the impulse from which story emerges within the human species (Boyd 2009, p. 130), but education researcher Vivian Gussin Paley spent her career advocating for the importance of fantasy play in the psychosocial development of young children (Paley 2004). A lifelong teacher of preschool and kindergarten, Paley constructed her theories about child development by transcribing and analyzing conversations that her own students had as they played with one another. Within her book A Child's Work: The Importance of Fantasy Play, Paley identifies play as important to the cultivation of social skills like inclusivity and "niceness," and she also suggests that play empowers children to test out ideas in open-minded ways.

In constructing his case for the "universal story grammar," Gottschall also engages with Paley's work, arguing that it demonstrates how, even in the youngest of children, play is observably always about confronting "trouble" (i.e., conflict) (Gottschall 2012). This is a large part of Gottschall's argument that conflict is universally foundational to story, and as an example of this, Gottschall records and analyzes a story told by a five-year old: “This is a story about a jungle. Once upon a time there was a jungle. There were lots of animals, but they weren't very nice. A little girl came into the story. She was scared. Then a crocodile came in. The end.'" (Gottschall 2012, p. 33). In his analysis of this story, Gottschall remarks that "trouble" is observable insofar as "a girl is menaced by a crocodile" (Gottschall 2012, p. 34). If one attends closely to the child's story, however, it is apparent that the little girl feels scared before the crocodile enters. In fact, there is no indication from the child storyteller as to how the crocodile behaves or whether it represents a sinister or benevolent presence. The decision to read the crocodile as "menacing," then, is the interpretive imposition of Gottschall's mind-a mind intent on reading the story through a framework of conflict. What is more, to the extent that children's stories do demonstrably engage with "trouble" or with real-world threats, the trouble rarely functions in a traditionally narrative way (Paley 2004); it does not escalate into a moment of crisis. Rather, trouble drifts in and out of the children's narratives-sometimes prompting a story to move in a new direction but rarely, if ever, creating the conditions for conclusion.

Corroborating this observation, sociolinguists Jenny Cook-Gumperz and Amy Kyratzis note that, although young children's stories often "report routine events," these narratives "lack a high point, either omitting an instigating problem event or omitting how the story is resolved" (Cook-Gumperz and Kyratzis 2005, p. 60). By addressing children's failures to include "instigating problem[s]" and "high point[s]" in their narratives, Cook-Gumperz and Kyratzis specifically indicate that children's stories lack conflictual premises and climactic apexes. What is more, they argue that even though these plot elements may eventually influence the narratives of older children, "the idealised story structure [i.e., the dominant plot model] is itself subject to cultural variation" (Cook-Gumperz and Kyratzis 2005, p. 60). Differentiating the "single experience" stories told by European-American children from the more collaborative storytelling practices of children in Japan, Cook-Gumperz and Kyratzis demonstrate that narrative formats are contextually bound. In direct contradiction to Gottschall, then, they highlight the idea that no sole story "grammar" innately emerges from human beings.

Moving away from Gottschall's emphasis on "trouble," Paley prefers to celebrate children's fantasy play for being both collaborative and open-ended (Paley 2004). Beyond aspiring to control a story in its entirety, children seem more concerned with ensuring that everyone has a chance to participate, and when this means that their stories must change course or that roles must be swapped, children are usually all too happy to accommodate. Rather than being locked into a conflictual storytelling model, then, these young storytellers are flexible both in their methods of creating-with 
multiple storytellers simultaneously "writing" a single story—as well as in their content. As an example of this flexibility, Paley tells of one student, Erik, who does not want to play the "bad guy" role initially assigned to him by his peers, so instead, the children invent for him the character of "a dad hunter who is bitten by a wolf and becomes wolf-like in strength" (Paley 2004, p. 23). This brief anecdote is significant, not only because the children prove that their story can be altered in the name of greater inclusion, but also because the story enacts a shift away from "bad guys" and "good guys" - that is, away from dualised conflict. A similar shift is echoed by Anthony, who-even as the sole author of his story-resists resorting to conflict as a narrative device: "This is Dracula and there is a dinosaur and they don't bite each other because they're friends'" (Paley 2004, p. 68). As Anthony demonstrates, a fictional story can exist in the absence of disharmony. Especially considering, then, that children's fantasy stories appear before children have been introduced to formulized plot models, they serve as early evidence that a story need not be based on conflict in order to maintain its designation as narrative.

If conflict, or "trouble," is not what draws children toward storytelling, what does seem to compel them is the possibility of limitless play. Part of the flexibility that children demonstrate is directly in service of being able to continue playing-that is, children will shift any aspects of their narratives precisely so that the narratives need not end. Paley explains that, "for children in their own stories, closure is not the goal" (Paley 2004, p. 80); rather, they want to be engaged in a process of ongoing discovery. To guide stories toward an ending would be to foreclose that discovery. Indeed, as Paley argues, children enjoy fantasy play because it allows them "to escape the limitations of established rituals" (Paley 2004, p. 92); they can rework those restrictive real-world patterns that have been presented to them as given. Their storyworlds, in other words, become the very avenues through which they feel themselves exhibiting agency.

Finally, although this aspect is less discussed by Paley, it is also arguable that fantasy play encourages children to empathize with nonhuman others. As has already been noted, Keen casts doubt upon the premise that narratives, in and of themselves, teach empathy (Keen 2007). James responds to Keen's suspicions, however, by appealing to the concept of the storyworld. Because anyone engaging with a storyworld must "model and imaginatively transport themselves" into an alternative landscape, narrative "makes possible the greater understanding of environmental representations...that empathic connections and behaviors rely upon" (James 2015, p. 213). Echoing this position-and expanding it into a more specific discussion of narratives that foreground animal consciousness-Herman contends that "narrative affords a bridge between the human and the nonhuman; stories provide this link not merely by allegorizing human concerns via nonhuman animals...but also by figuring the lived phenomenal worlds" of their animal characters (Herman 2011, p. 159). For both Keen and Herman alike, then, the real power of story does not necessarily exist in its capacity to generate empathy. Rather, what is more important is that stories require their audiences to engage with "phenomenal worlds" that differ from their own. As such, they encourage audiences to think from new-and sometimes nonhuman-perspectives.

With this in mind, it is especially significant that children frequently enact their stories as they are narrating them, for such an enactment requires an embodied engagement with a storyworld. Thus, children not only talk about rabbits and trees, they experience becoming those rabbits and trees. In this way, they use story to see and feel from the perspective of nonhumanity. Keta, for instance, describes a river who is crying because "'It was so sad from having too much water so it couldn't get anyone to play there and it got lonely'" (Paley 2004, p. 82). Here, Keta demonstrates her capacity to think as a river: When the river floods, it is no longer safe for people to play within it, which causes the river to feel lonely. Fantasy play has thus enabled Keta to investigate the implications of a real-world phenomenon, but she is not merely considering how she, as a human, might experience a flood; rather, she considers what it means to a river itself to flood.

Even in the brief transcripts supplied by Paley's book, then, many of the storytelling approaches advocated by Morton and other eco-humanities theorists have been enacted. When children tell stories, 
they do not exist outside of or above their narratives. Because they do not know how a story will end-and, indeed, because they typically do not desire an ending-there is nothing that they are building toward. Indeed, Peter Brooks says of endings that they supply "the order and significance of plot" (Brooks 1984, p. 94). It is the ending, in other words, that allows a storyteller to retroactively shape various events into the dominant plot model. In order to craft a successful narrative "arc" - one that mounts in tension as it climbs toward a climax-the narrator must have already identified the moment when things were at their very worst. To tell a story without knowing the ending, however, is to necessarily redirect one's attention toward the relational exchange of the story's characters. When children engage in the collaborative storytelling of playacting, they must rely purely on the causal experience of what happens in a moment-to-moment way. The story cannot know where it is going.

Equally important, children's storytelling practices are based on cooperation rather than competition. They are able to evolve-to continue without ending-precisely because they shift in accordance with the needs of all involved. Truly, the ethos of children's fantasy play-in all of its imaginary embodiments of flora and fauna-is one of with, not for. Children do not seek to pre-determine what will happen to a "nonswimming aardvark" lost on the other side of a poison river; they seek to become the aardvark and find out for themselves (Paley 2004, p. 74). This is why Paley recommends using story as a tool for classroom management. Children's storytelling practices are so adaptable that, rather than simply telling children to stop playing when, for instance, their play becomes too noisy, a teacher might just as easily introduce a constraint into the fantasy scenarioan imaginary reason why the characters themselves need to be quieter. The children will respond to the constraint by directing their narrative in a new way.

For reasons demonstrated by preschoolers, then, theories of play are the perfect basis from which to rethink the dominant plot model. To be sure, narrative and play already have a rich history of interacting via literary experiments with form: "We think of the spirit of play," suggests Marie-Laure Ryan, "as typical of postmodern narratives" (Ryan 2005, p. 355). And indeed, the entire field of "unnatural" narratology is devoted to texts that "play with, ignore, or transgress" mimetic conventions (Richardson 2012, p. 22). Not only is play intimately linked to story, however, but it has also long been endorsed by various ecological movements. One of the tenets of the Deep Ecology movement, for example, advocates "return[ing] play to its place as the nursery of individual fulfillment and cultural achievement" (Devall 2008, p. 158). Environmental educators have also recognized the developmental importance of humans' playful relationships with nonhumanity-their "loving and joyful immersion[s] in the local web of life" (Vickers 2003). Perhaps most importantly, play has been identified as representing a non-hierarchical, interactional sphere that humans and nonhumans already share: Not only do animals and humans instinctually know how to play, they also often know how to play with one another (Huizinga 1949). At its root, then, play comes before any divisions of nature and culture. As such, it inherently works toward one of the stated goals of the environmental humanities: to "unsettle" exclusively human narratives (Rose et al. 2012, p. 3).

One of the first important figures to write about play was Johan Huizinga, whose Homo Ludens: A Study of the Play Element in Culture makes two crucial arguments about play: (a) that play can only happen in full freedom (Huizinga 1949, p. 8); and (b) that play is done only for play's sake, which makes it both non-materialistic and meaningful (Huizinga 1949, p. 6). Thus, because animals and humans are capable of playing with one another, they already have systems in place for exchanging meaning. What is more, since play cannot possibly exist if it is forced to any degree, it is synonymous with choice. Accordingly, a playful interaction is inherently meaningful insofar as it involves at least two parties-human or nonhuman-choosing to be with one another.

Since the appearance of Huizinga's foundational text, many theorists have built upon his ideas, revising and expanding them in new directions. Roger Caillois, for instance, corrects Huizinga by suggesting that some play, like gambling, is expressly materialistic (Caillois 2001, p. 5). Insofar as this project is concerned, however, Caillois's theories are most relevant in that he sees games as divisible 
into those that are "ruled" and those that are "make-believe" (Caillois 2001, p. 9). Identifying the latter category as being based upon mimicry - the same category into which Paley's children's fantasy play fits-Caillois makes note of insects, birds, and even crabs, who all exhibit an impulse toward imitation. Interestingly, he defines mimicry as "incessant invention" (Caillois 2001, p. 23), pointing out that, in the case of humans, it is mimicry that leads to the role-playing innovations of story. What is more, Caillois suggests that narrative is, in fact, premised upon the idea of fictional worlds, and as such, it cannot emerge from rule-bound games that result in winners and losers. Although this perspective has been disproved since the development of "quest-type" video games (Ryan 2005), Caillois's early connection between narrativity and fictional worlds seems an interesting predecessor to the concept of the storyworld.

More recently, Miguel Sicart has advocated treating play as a "portable tool for being" (Sicart 2014, p. 2) - a way of interpreting and engaging the complex of relationships that constitute one's world. Sicart identifies his theory as a "playful call to arms...against efficiency, seriousness, and technical determinism" (Sicart 2014, p. 5). He sees play as a force of resistance to values, like efficiency, that often go unquestioned but-as evidenced by the Pew report (Carlin et al. 2008)—can become justifications for barbarism (to invoke Stengers's term) (Stengers 2015). For Sicart, play's capacity for resistance is expressly linked to its "appropriative" quality-its ability to overtake "events, structures, and institutions to mock them and trivialize them" (Sicart 2014, p. 3). This appropriation has value insofar as it "reambiguates" the world-defying set codes and allowing players to return to a state of wonder (Sicart 2014, p. 3). Much like Paley identifies fantasy play as helping children to exercise control over rules presented to them as inviolable (Paley 2004), then, Sicart sees play as encouraging an agency that simultaneously invites a new way of seeing; what was taken as serious and unchanging, once interpreted in a playful context, becomes infinitely more open to influence.

Echoing the capacity of play to reinvigorate wonder-and in a decided turn away from dualism - poet Diane Ackerman contends that "In all forms of deep play, one becomes fascinated by an 'other,' in whose presence one feels exaltation" (Ackerman 1999, p. 87). Broadening the description of the "other" in an object-oriented way, Ackerman adds that the "other" might very well be "a war, a mountain, or a bicycle" (Ackerman 1999, p. 87). Regardless of who or what the "other" is, however, playful interactions stem from a place of respectful curiosity. A player who "exalts" in the presence of another cannot also instrumentalize or devalue that other. Hypothetically, then, play can become a "tool for being," as Sicart has advocated, whenever one approaches one's relationships from a place of reverence.

All of these theories find a certain synthesis-as well as a relevance to narrative-within James P. Carse's Finite and Infinite Games (Carse 1986). Similar to Caillois's distinction between ruled and make-believe games, Carse suggests that there are only two types of games in existence: finite games, which are played to be won, and infinite games, which are played for the purpose of keeping play going. Because a finite game is building towards an ending in which one party wins, the game is bound by spatial and temporal rules that cannot change. Because infinite games, by contrast, strive to keep play going, they must overcome any spatial or temporal limits that threaten an end to play. In this way, "Finite players play within boundaries; infinite players play with boundaries" (Carse 1986, p. 12). The finite game, then, is like the dominant narrative structure, which derives its meaning through conclusion-through an announcement, as it were, of a victor. An infinite game, on the other hand, is much more representative of evolution, which confronts boundaries through adaptation, striving always for continued life (Boyd 2009).

Elaborating upon the infinite game, Carse suggests that "the only purpose of the game...is to keep everyone in play" (Carse 1986, p. 9). Whereas a finite player seeks to remove other players from a game, an infinite player sets up the conditions most likely to facilitate another's flourishing, such that play has the best chance of continuing. This is, of course, a vision that thinks toward cooperation rather than conflict-privileging ecosystemic interests over personal ones, even when stakes are at their highest: 
Infinite players die. Since the boundaries of death are always part of the play, the infinite player does not die at the end of play, but in the course of play...It does not mean that the game comes to an end with death; on the contrary; infinite players offer their death as a way of continuing play. For that reason they do not play for their own life; they live for their own play. But since that play is always with others, it is evident that infinite players both live and die for the continuing life of others (Carse 1986, p. 31).

Playful even in his descriptions of dying to keep infinite play going, Carse points to the very serious spirit with which infinite play is undertaken. Dedicated to keeping the game going at all costs, the infinite player recognizes that even one's personal death can be offered in service of others' access to continued play.

Through Carse's framework of the infinite game, Morton's proposals for art after "the end of the world" appear instantly more concrete. Morton repeatedly stresses that in the absence of a world, all that persists is "intimacy" - "a number of unique beings...to whom I owe an obligation through the simple fact that existence is coexistence" (Morton 2013, p. 125). Emphasizing that the experience of being alive is defined only through relationships, Morton argues that we are each "obligated" to treat the other well-to use our "turns" as infinite players to ensure that other beings stay in play. Morton even explicitly speaks about "care," suggesting that the particular challenge for humans at this moment in time is to learn to care for "fatal" objects like nuclear waste, which will surely outlast our descendants and will perhaps also outlast humankind as a totality (Morton 2013, p. 124). To exercise care even for the fatal — until and beyond a personal death — is precisely what Carse is referencing when he speaks of infinite players dying for the continued life of others. Indeed, the incredible suggestion that Carse is making is that one must conceive even of one's own life in the absence of a telos, with the only directive guiding one's behaviors being the desire that others-human and nonhuman, alike-are set up to thrive (Carse 1986). Morton wants an "ethics of the other" (Morton 2013, p. 121), and Carse supplies it.

If the infinite game has anything especially important to teach, then, it is an openness toward the future and a fearlessness toward limitations. Carse makes it clear that "we do not play against reality; we play according to reality" (Carse 1986, p. 38). The given conditions of the planet, in other words, are the very boundaries that may threaten to end play and that must, consequently, be played with. In this sense, even though environmental crisis legitimately imperils the human's ability to stay in a playful relationship with the nonhuman world, there is a way of playfully engaging even the notion of crisis. To play with crisis, we humans must learn to compose with it—as it exists both in our external environments and in our stories. If we can abandon the finite idea that crisis always brings conclusion, then we can embrace crisis's invitation to become infinite and adaptive players. Part of becoming infinite players, of course, will mean disengaging from conflictual frameworks and appealing, instead, to a vision that prizes the wellbeing of the whole over the seductions of personal success. Indeed, within the infinite game, there is no narrative space for competition; there are only boundaries, which—failing to supply a lasting ending to the story-demand adaptation instead.

To be sure, this is a dramatic vision of play, but Carse even indicates that whereas finite play is akin to theatre-with its script composed according to set rules-infinite play is inherently "dramatic" (Carse 1986, pp. 20-21). Precisely because it operates in the absence of outcome, its trajectory is significant not in its totality, but in the moment-to-moment direction it takes. Finite players win games by surprising their opponents, but infinite players learn to expect the unexpected-that is, they prepare themselves to meet surprise with personal, often dramatic, transformation (Carse 1986, p. 23). It is here, in this discussion of surprise that is met by transformation, that Carse follows in the footsteps of Paley-observing those qualities of (infinite) play that enable an open-ended narrative. Indeed, for the child whose foremost desire is to continue playing, surprise — or "trouble"—is unable to deliver a blow strong or lasting enough to end a story; surprise simply interjects an unexpected parameter, which then sends the story in a new direction. 
In this spirit, apart from promoting play as a helpful framework through which to live one's life, I am also specifically advocating that play become the motivating logic of the eco-narrative. Indeed, Sicart's celebration of play's capacity to appropriate "known structures" seems an overt invitation to play to overtake and appropriate the structure of the dominant plot model (Sicart 2014). To teach people to perceive story differently - with a renewed sense of wonder inspired by an exaltation in the other (Ackerman 1999) - will be to disrupt the logic of concepts like economic efficiency, which unabashedly position the economic interests of some at the expense of others. Because stories supply interpretive frameworks (Brooks 1984), they are the means through which new perceptions and new ways of relating can be taught. For the same reason, they remain-even in "catastrophic times" (Stengers 2015) - a palpable mechanism for guiding the adaptations of our species. The human evolution toward an ethos of the other, then, can (and should) be led by a storytelling practice appropriated by infinite play - the only real tenet of which is to move toward an open-ended future by acting, moment-to-moment, with cooperative rather than conflictual motives.

\section{The Eco-Narrative in Practice}

In his preface to Catastrophism, after lamenting the defeatism that often accompanies discussions of environmental crisis, economist Doug Henwood muses: “Wouldn't it be better to spin narratives of how humans are marvelously resourceful creatures who could do a lot better with the intellectual, social, and material resources we have?" (Henwood 2012, p. 15). Agreeing with Henwood that it would be better-and inspired by the same basic belief that narrative can empower humanity toward increased resourcefulness-I here arrive at the eco-narrative.

Premised upon a belief articulated by feminist narrative theorist Robyn Warhol that "Deviations from formal norms make deviations from dominant ideology visible" (Warhol 2012, p. 12), the eco-narrative uses the concept of infinite play to rethink the dominant plot model, thereby exposing the fundamental environmental irresponsibility of a storytelling practice motivated by conflict. Indeed, by infusing narrative with the philosophy of infinite play-namely, the desire to keep a story going for as many of its characters for as long as possible- the eco-narrative explicitly foregrounds ecosystemic goals over individual ones. Insofar as it plays with form in order to communicate ideology, it can rightly be conceived as participating in the antimimetic tradition (Herman 2012), and indeed, many "unnatural" works of fiction might retrospectively (and with some irony) be classified as eco-narratives. Since the interest of this article, however, is in narrative production - that is, in thinking toward how the storyteller can narrativize her own environments and experiences without retrofitting them into the dominant plot model - I think that it will be useful here to address the eco-narrative through the lens of the "self-narrative" (Herman 2014).

Even though his article performs an analysis of a fictional short story, Herman's "Narratology Beyond the Human" is rooted in the concept of the "self-narrative"-a term psychologists Kenneth J. Gergen and Mary M. Gergen use to describe the human practice of taking events from one's life and organizing them into coherent narratives (Herman 2014). Reading Lauren Groff's "Above and Below" as an example of self-narrative, Herman argues that the protagonist of Groff's story must "reconstruct" her own self-narrative as she increasingly recognizes "her place within a world that extends beyond the human" (Herman 2014, p. 133). Herman is ultimately interested in Groff's story as an example of how self-narratives can become more inclusive of nonhumanity-"locat[ing] the human agent in a transspecies constellation of selves" (Herman 2014, p. 133). I see this interest as very much in line with the interests of the eco-narrative. Because we humans are in a constant production of self-narrative(s) - translating relationships and events from our lives into stories that we can retell to ourselves and to others-it is important to consider how these self-narratives either resist or reaffirm the dominant plot model. As Herman makes clear, self-narratives can become eco-narratives simply by giving greater consideration to how they situate the self vis-à-vis the story's other (nonhuman) characters. 
Keeping in mind Herman's interest in stories that locate the self within a larger "transspecies constellation of selves," I think it is worthwhile, at this point, to look closely at a story that rightfully earns the title of eco-narrative. Another story about human/animal relations, this one comes from a scholarly essay co-written by Annette Watson and Orville H. Huntington called "They're here-I can feel them: the epistemic spaces of Indigenous and Western Knowledges" (Huntington and Watson 2008). In this piece, Watson, who is a doctoral student and an academic geographer, and Huntington, who is an Athabascan hunter and gatherer, share the narrative task of describing a moose hunt. Here is an excerpt:

We had been traveling for about an hour, and as the boat made a left around the bend, suddenly there appeared a big bull looming on the bank, its antlers spread wide across its body. It saw us - but didn't move...For a moment no one spoke, and then Orville said, 'Wow-he was really trying hard to give himself to us.' Non-natives often employ the verb 'to take' to describe hunting...But the Koyukon believe that hunters do not 'take' anything; instead animals choose to give themselves to the hunter. The 'gift' is made as a result of the 'luck' of the hunter, and a hunter has luck when he has been respectful. Respect is the act of following strict rules that guide one's behavior and actions toward or away from the animal and all other living and non-living things. In the Koyukon language, such taboos are referred to as 'hutlanee'...Most significantly, it is hutlanee to talk about animals, especially make fun of them, such as calling them 'stupid.' There are very few things people should do, and many things that are hutlanee. About the only thing a person does is to accept them, accept the animal's life and spirit and body when it chooses to give itself. I told Annette that you also accept a moose's past; 'they're like us, they have a story behind them' (Huntington and Watson 2008, pp. 260-61).

Ostensibly another narrative concerning the human practice of killing animals, this story appears as wholly different than that of IFAP. In the foremost, the human actors in the story are not in conflict with the nonhuman ones. Even though the humans are on a hunting trip, they have no intention of "taking" an animal's life against the animal's will; rather, they wait until an animal "gives" himself to them. Thus, all characters are in cooperation from the beginning. What is more, whereas the CAFO animal is a symbolic "production unit," incapable of autonomy but acted upon by humans, the moose in this story is fully agential. As part of his agency, he is in possession of his own life as well as his own story; he does not represent an instrumentalized figure through whom a human protagonist realizes his own narrow needs. Just as an infinite player "offers" his own death in the service of others' continued play, the moose decides to die as a "gift" toward the continued life of the hunters.

Perhaps even more radical in this story is its use of two narrators. The shift is subtle, but the passage moves from first-person narration by Watson into first-person narration by Huntington, with the move becoming evident only when one narrator refers to the other by name. The largest implication of this shared narration system is the degree to which it resists a singularity of perspective. It is impossible to locate a protagonist in this story, precisely because no one voice is being amplified above the others. Indeed, not only are the voices of Watson and Huntington both represented as narrators, but the moose's voice is represented through the narrators' careful attention to his actions. Noting both his stillness and the direction of his gaze, Huntington reads the moose's movements as the communications through which he signals his offering. Ultimately, then, Watson and Huntington not only speak about the respect that the hunter must have for the nonhuman, they also use their shared literary space to model this respect, both toward the moose and toward each other. By never using the narrator's voice to speak for one another, they remain in constant dialogue-continually receiving and responding to the perspectives offered by all three of the characters.

Importantly, Watson and Huntington's story also provides concrete guidelines for how humans should enact their respect toward nonhumans. Echoing Morton's calls for an object-oriented art that is always already a collaboration with nonhumanity, Watson and Huntington explain that it is disrespectful even "to talk about animals." This can be taken to apply not only to in-person 
conversations "about animals," but to written words as well: In representing an animal on the page, the narrator must not manipulate the animal to serve his own narrative ends. Instead, he should approach the animal respectfully, by acknowledging its autonomous ability to influence the story.

Of course, here, some might argue that it is fundamentally impossible to tell a story "with" another being if one is the sole storyteller. That is, any attempt at storytelling-unless it is a cocreation akin to Watson and Huntington's or to children's collaborative fantasy play-will result in some narrative talking about the other. Indeed, my earlier claim that the moose in this story exhibits agency insofar as he "gives" himself to the hunters might itself come off as highly suspect. After all, how can an animal be said to exert influence within a written medium - that is, within a language system that is not its own? Acknowledging the wide debate that surrounds this question, Heise explains that "Some eco-critics have asked whether a medium such as literature, which relies entirely on human language, can possibly reflect anything other than a deeply anthropocentric view of nature." (Heise 2005, p. 130). In response, James has suggested that there is nothing wrong with embracing the anthropocentric (James 2015); why shouldn't we be transparent about the "role of the human imagination in the perception of the environment" (James 2015, p. 30)? Others have extended this line of argument to suggest that the benefits of (the attempt at) representing nonhuman consciousness on the page far outweigh the drawbacks. Herman, for example, contends that "By modeling the richness and complexity of 'what it is like' for nonhuman others, stories can underscore what is at stake in the trivialization-or outright destruction-of their experiences" (Herman 2011, p. 159). In his estimation, what is of greatest importance is that people are engaging in the imaginative exercise of thinking from a nonhuman perspective. Whether or not the animal's consciousness is faithfully recreated is of less consequence.

Although I am generally sympathetic to Herman's argument, I also maintain that, in the above story, Huntington and Watson manage to accurately depict the moose, and the moose does exert agency within the text. To my mind, this is because Huntington's philosophy is, at root, a phenomenological one. He is able to translate the moose's movements into human language because his translation comes from a place of embodied, respectful witnessing. For Morton, as for early phenomenologists like Husserl, no object can ever be known its entirety, thus: "Objects withdraw, such that other objects never adequately capture but only (inadequately) 'translate' them" (Morton 2011, p. 166). By appealing to the ultimate inaccessibility of all entities-be they animals, objects, or hyperobjects-Morton simultaneously acknowledges that any attempt to understand the other requires a "translation" of it; it means perceiving the object without being able to fully know or possess it. Yet if this premise is taken to be true, then all acts of self-narration-not just the human effort to speak about an animal—should theoretically be subject to the same line of questioning aimed at Huntington and Watson's text: Is the attempt to represent an object on the page, by its very nature, an anthropomorphizing act?

In her book Vibrant Matter, Jane Bennett occupies a similar position to Morton but intersperses her theoretical discussions with moments of phenomenological exaltation in the object other. Discovering a glove, a dead rat, a bottle cap (and more) in a grate above a storm drain in Baltimore, Bennett watches as these objects begin to "shimmer and spark" in her perception (Bennett 2010, p. 5). Part of what makes these objects shimmer, Bennett explains, is "a certain anticipatory readiness on [her] in-side" —"a perceptual style open to the appearance of thing-power" (Bennett 2010, p. 5). Bennett approaches the objects she encounters with an attitude that is "open" and ready to receive them, and as such, she is predisposed for appreciation. In this way, when she uses the term "thing," she does not do so in an attempt to devalue that which she sees. Rather, she recognizes herself as comprising a network with the objects she encounters. She too is a thing to them, and no one thing gets to have a privileged position above the others. As she thinks through the logic of it: "to begin to experience the relationship between persons and other materialities more horizontally, is to take a step toward a more ecological sensibility" (Bennett 2010, p. 10). For Bennett, then, true ecological thinking begins with horizontal relationships-with radically repositioning one's self as the equal to animals, plants, rocks, and all else that is material. 
It is significant to me (and to the project of the eco-narrative) that Bennett speaks of objects without defaulting into objectification. She does not do as the Pew report does, for instance-using symbolism to exercise narrative domination over another. Rather, Bennett's ontological framework reveals itself as most akin to that proposed within Ackerman's theory of "deep play" (Ackerman 1999). Both Ackerman and Bennett practice a mode of being in the world that marvels at intercorporeality and that defaults into a state of awe toward the other.

Following in their philosophical footsteps, I am suggesting that, as it shows up in self-narrative, the storytelling equivalent of "deep play" is a documentation of the nonhuman other that does not seek to possess or manipulate the other-never professing to have access to the other's interiority, but beginning, instead, from a place of respectful witnessing. Insofar, then, as Watson and Huntington's narrative relationship to the moose is guided by reverent attention to its behaviors-and insofar as the moose determines its own entrance and exit from the story (Huntington and Watson 2008) - I argue that it enacts as much agency as it possibly can within a human documentary mode.

Finally, it is significant to the eco-narrative project that Huntington and Watson tell a story that is not ultimately framed as a tale about "the moose that got away" - with the climatic moment appearing, for instance, as the moose narrowly escapes. To tell such a story would, indeed, be robbing the moose of its agency by making it subservient to a pre-determined plot model. Instead, however, the story finds its structure through the conversational narration of all of the story's characters. Respectful dialogue drives the plot forward.

This dialogic structure is, of course, intentional on the part of the authors, who outline their own project within the terms of posthumanism: "The 'posthuman' does not imply a historical era, but an interrogation of humanists' static boundaries between humans and nonhumans, culture and nature" (Huntington and Watson 2008, p. 258). It is perhaps the posthuman framework, then, that makes the story so identifiably an eco-narrative. Indeed, even Huizinga's earliest conceptions of play define it as an activity that equally belongs to nature and culture (Huizinga 1949). Inspired by playful attempts to play with boundaries, both the eco-narrative and the posthuman narrative advocate stylistic explorations that upset the dominant narrative's long unquestioned practice of privileging the interests of a single protagonist.

Inspired by Huntington and Watson's storytelling practices-and in the spirit of empowering humans toward playful cooperation in the face of ongoing crisis-the eco-narrative's only real directive is finally quite simple: to apply concepts from play theory to the act of storytelling and then to play with those concepts. Rather than outlining set rules, infinite play merely presents narrative (whether rooted in self-narrative or in fiction) with an invitation to move in unforeseen directions-shifting narrators, blurring the distinctions between humans and nonhumans, and transitioning freely between tenses, languages, locations, and time periods (to name just a few ideas). What is more, in seeking to remove the narrator from any omniscience that would allow her distance from the story she is telling, the eco-narrative also desires to relate its stories from within. The eco-narrator embarks on a storytelling project without knowing the end of the story and, indeed, without even desiring an ending. In the absence of a foreknown trajectory, eco-narrators instead advance their narratives through the relationships of their characters. Treating humans and nonhumans with equal reverence, the eco-narrative is therefore guided by an exaltation in the other. In fact, knowing that competition between its characters would dualise the story into one of winners and losers-that is, into finitude-the eco-narrative dispenses altogether with conflict as a dramatizing device. It remains dramatic, however, both because its characters are willing to undergo large transformations in service of another and because the eco-narrator is personally invested in the well-being of each of her characters. Ultimately following the very example set by evolution, then, the eco-narrative approaches every narrative boundary-be it one of time, place, or resource-as an invitation for creative adaptation.

Children tell eco-narratives when they invent magic pillows that allow aardvarks to float across poison rivers (Paley 2004, p. 74). Timothy Morton tells an eco-narrative when he demands that weather be treated not as a backdrop, but as a legitimate character in the human/Earth story (Morton 2013). 
Facing increasing catastrophe and the very real possibility of our species-wide demise, we humans can tell eco-narratives by choosing to recognize that, even when we die, other beings will remain to continue the story. We will be telling an eco-narrative, in other words, by including those future beings in our stories now. Indeed, if we are to transform our self-narratives into eco-narratives, all we really need to do is remember: Stories are avenues for communion. Yes, we tell stories to each other, but we also tell them to be with each other.

Conflicts of Interest: The author declares no conflict of interest.

\section{References}

Ackerman, Diane. 1999. Deep Play, 1st ed. New York: Random House, p. 87.

Baldick, Chris. 2004. The Concise Oxford Dictionary of Literary Terms, 2nd ed. Oxford: Oxford University Press, pp. 251-52.

Bataille, Georges. 2011. Theory of Religion. In Princeton Readings in Religion and Violence. Edited by Mark Juergensmeyer and Margo Kitts. Princeton: Princeton University Press, pp. 167-73.

Bennett, Jane. 2010. Vibrant Matter: A Political Ecology of Things. Durham: Duke University Press.

Bernaerts, Lars, Marco Caracciolo, Luc Herman, and Bart Vervaeck. 2014. The Storied Lives of Non-Human Narrators. Narrative 22: 68-93. [CrossRef]

Boyd, Brian. 2009. On the Origin of Stories: Evolution, Cognition, and Fiction. Cambridge: Belknap Press of Harvard University Press.

Brooks, Peter. 1984. Reading for the Plot: Design and Intention in Narrative, 1st ed. New York: A.A. Knopf.

Buell, Frederick. 2003. From Apocalypse to Way of Life: Environmental Crisis in the American Century. New York: Routledge. Caillois, Roger. 2001. Man, Play, and Games. Translated by Meyer Barash. Urbana: University of Illinois Press.

Carlin, John, Michael Blackwell, David Andrews, Fedele Bauccio, Tom Dempster, Dan Glickman, John Hatch, Frederick Kirschenmann, James Merchant, Marion Nestle, and et al. 2008. Putting Meat on the Table: Industrial Farm Animal Production in America, Pew Commission's report on Industrial Farm Animal Production. Available online: http://www.livablefutureblog.com/pdf/Putting_Meat_on_Table_FULL.pdf (accessed on 7 April 2017).

Carse, P. James. 1986. Finite and Infinite Games: A Vision of Life as Play and Possibility. New York: Random House.

Cook-Gumperz, Jenny, and Amy J. Kyraztzis. 2005. Children's Storytelling. In Routledge Encyclopedia of Narrative Theory. Edited by David Herman, Manfred Jahn and Marie-Laure Ryan. New York: Routledge, pp. 60-62.

Devall, Bill. 2008. The Deep Ecology Movement. In Ecology: Key Concepts in Critical Theory, 2nd ed. Edited by Carolyn Merchant. Amherst: Humanity Books, pp. 149-63.

Dibell, Ansen. 1988. Plot, 1st ed. Cincinnati: Writer's Digest Books, p. 126.

Dobrin, I. Sidney, and Christian R. Weisser. 2002. Natural Discourse: Toward Ecocomposition. Albany: State University of New York Press.

Gottschall, Jonathan. 2012. The Storytelling Animal: How Stories Make Us Human. Boston: Houghton Mifflin Harcourt. Haraway, J. Donna. 1999. Situated Knowledges: The Science Question in Feminism and the Privilege of Partial Perspective. In The Science Studies Reader. Edited by Mario Biagioli. New York: Routledge, pp. 172-88.

Harmon, William, and Hugh Holman. 2003. A Handbook to Literature, 9th ed. Upper Saddle River: Prentice Hall, p. 387.

Heise, K. Ursula. 2005. Eco-Narratives. In Routledge Encyclopedia of Narrative Theory. Edited by David Herman, Manfred Jahn and Marie-Laure Ryan. New York: Routledge, pp. 129-30.

Henwood, Doug. 2012. Dystopia Is for Losers. In Catastrophism: The Apocalyptic Politics of Collapse and Rebirth. Edited by Sasha Lilley. Oakland: PM Press, pp. 9-15.

Herman, David. 2005a. Conflict. In Routledge Encyclopedia of Narrative Theory. Edited by David Herman, Manfred Jahn and Marie-Laure Ryan. New York: Routledge, p. 83.

Herman, David. 2005b. Structuralist Narratology. In Routledge Encyclopedia of Narrative Theory. Edited by David Herman, Manfred Jahn and Marie-Laure Ryan. New York: Routledge, pp. 571-76.

Herman, David. 2011. Storyworld/Umwelt: Nonhuman Experiences in Graphic Narratives. SubStance 40: 156-81. 
Herman, David. 2012. Exploring the Nexus of Narrative and Mind. In Narrative Theory: Core Concepts and Critical Debates. Edited by David Herman, James Phelan, Peter J. Rabinowitz, Brian Richardson and Robyn Warhol. Columbus: Ohio State University Press, pp. 14-19.

Herman, David. 2014. Narratology Beyond the Human. Diegesis 3: 131-43.

Huizinga, Johan. 1949. Homo Ludens: A Study of the Play-Element in Culture. Translated by R. F. C. Hull. London: Routledge \& K. Paul, pp. 11-220.

Huntington, H. Orville, and Annette Watson. 2008. They're here-I can feel them: The epistemic spaces of Indigenous and Western Knowledges. Social Cultural Geography 9: 257-81.

James, Erin. 2015. The Storyworld Accord: Econarratology and Postcolonial Narratives. Lincoln: University of Nebraska Press.

Keen, Suzanne. 2007. Empathy and the Novel. Oxford: University Press.

Kress, Nancy. 1993. Beginnings, Middles, and Ends, 1st ed. Cincinnati: Writer's Digest Books, p. 71.

Lilley, Sasha. 2012. The Apocalyptic Politics of Collapse and Rebirth. In Catastrophism: The Apocalyptic Politics of Collapse and Rebirth. Edited by Sasha Lilley. Oakland: PM Press, pp. 1-14.

Lilley, Sasha, David McNally, Eddie Yuen, and James Davis. 2012. Catastrophism: The Apocalyptic Politics of Collapse and Rebirth. Oakland: PM Press.

Matheny, Gaverick. 2006. Utilitarianism and Animals. In In Defense of Animals: The Second Wave. Edited by Peter Singer. Malden: Blackwell, pp. 13-25.

Morton, Timothy. 2011. Here Comes Everything: The Promise of Object-Oriented Ontology. Qui Parle: Critical Humanities and Social Sciences 19: 163-90. [CrossRef]

Morton, Timothy. 2013. Hyperobjects: Philosophy and Ecology after the End of the World. Minneapolis: University of Minnesota Press.

Paley, Gussin Vivian. 2004. A Child's Work: The Importance of Fantasy Play. Chicago: University of Chicago Press.

Plumwood, Val. 1993. Feminism and the Mastery of Nature. New York: Routledge, pp. 41-68.

Richardson, Brian. 2012. Antimimetic, Unnatural, and Postmodern Narrative Theory. In Narrative Theory: Core Concepts and Critical Debates. Edited by David Herman, James Phelan, Peter J. Rabinowitz, Brian Richardson and Robyn Warhol. Columbus: Ohio State University Press, pp. 20-25.

Rose, Bird Deborah, Thom van Dooren, Matthew Chrulew, Stewart Cooke, Matthew Kearnes, and Emily O'Gorman. 2012. Thinking through the Environment, Unsettling the Humanities. Environmental Humanities 1: 1-5. [CrossRef]

Ryan, Marie-Laure. 2005. Narrative, Games, and Play. In Routledge Encyclopedia of Narrative Theory. Edited by David Herman, Manfred Jahn and Marie-Laure Ryan. New York: Routledge, pp. 354-56.

Scranton, Roy. 2015. Learning to Die in the Anthropocene: Reflections on the End of a Civilization. San Franciso: City Lights Books, pp. 13-27.

Sicart, Miguel. 2014. Play Matters. Cambridge: MIT Press.

Stengers, Isabelle. 2015. In Catastrophic Times: Resisting the Coming Barbarism. Translated by Andrew Goffey. London: Open Humanities Press. Available online: http:/ /openhumanitiespress.org/books/download/ Stengers_2015_In-Catastrophic-Times.pdf (accessed on 7 April 2017).

Vickers, Valerie. 2003. An Exploration of Ecological Identity: Education to Restore Human/Earth Relationship. Ph.D. dissertation, University of North Carolina, North Carolina, NC, USA.

Warhol, Robyn. 2012. A Feminist Approach to Narrative. In Narrative Theory: Core Concepts and Critical Debates. Edited by David Herman, James Phelan, Peter J. Rabinowitz, Brian Richardson and Robyn Warhol. Columbus: Ohio State University Press, pp. 9-13.

White, Hayden. 2002. The Historical Text as Literary Artifact. In Narrative Dynamics: Essays on Plot, Time, Closure, and Frames. Edited by Brian Richardson. Columbus: Ohio State University Press, pp. 191-210.

(C) 2017 by the author. Licensee MDPI, Basel, Switzerland. This article is an open access article distributed under the terms and conditions of the Creative Commons Attribution (CC BY) license (http://creativecommons.org/licenses/by/4.0/). 